\title{
Health risk assessment of heavy metals via consumption of bivalves species in Kota Kinabalu, Sabah, Malaysia
}

\begin{abstract}
Bivalve organisms are more vulnerable to a variety of aquatic pollution. It has high adaptability to various levels of contaminations. It can accumulate pollutants such as heavy metal in its tissues and cause major concern on potential risk of heavy metal especially to the consumers. The objectives of this study were to determine heavy metal $(\mathrm{Cu}, \mathrm{Zn}, \mathrm{Pb}$ and $\mathrm{Cd})$ concentrations in five most consumed and popular bivalve species among Kota Kinabalu community and to compare with the Food Regulation Malaysia (1985) and Food and Agriculture Organization. Five most consumed bivalves species are Meretrix meretrix (Kepah), Anadara granosa (Kerang), Tridacna squamosa (Kima), Polymesoda erosa (Lokan) and Crassostrea gigas (Tiram). Health risk associated with these heavy metals in the five bivalves species were estimated based on target quotients (THQs). The results indicated that the metal concentrations in the bivalves ranged from 3.21 to $36.22 \mathrm{mg} / \mathrm{kg}$ for $\mathrm{Cu}, 28.62 \mathrm{i}$ $1771.12 \mathrm{mg} / \mathrm{kg}$ for $\mathrm{Zn}, 0.20 \ddot{1} 3.43 \mathrm{mg} / \mathrm{kg}$ for $\mathrm{Pb}$ and $0.44 і ̈ 7.27 \mathrm{mg} / \mathrm{kg}$ for $\mathrm{Cd}$. These concentrations were significantly correlated with species and the size of bivalves. Some of the heavy metal concentrations exceeded the permissible level by Food Regulation Malaysia (1985) and Food and Agriculture Organization. However, based on the THQs value for adults, only metal concentrations in Crassostrea gigas (Tiram) exceeded, which indicates potential health risks associated with the consumption of this species.
\end{abstract}

Keyword: Bivalves; Heavy metals; Health risk; Target hazard quotients (THQs) 